\title{
Checklist of medium-sized to large mammals of Campos Gerais National Park, Paraná, Brazil
}

\author{
Alan Deivid Pereira ${ }^{1}$, Sergio Bazilio ${ }^{2}$, Mário Luís Orsi ${ }^{3}$ \\ 1 Programa de Pós-Graduação em Ciências Biológicas, AC: Biodiversidade e Conservação de Habitats Fragmentados. Universidade Estadual de \\ Londrina, Centro de Ciências Biológicas, Rodovia Celso Garcia Cid, PR 445, Km 380, CEP 86.057-970 - Londrina, Paraná, Brazil. 2 Universidade \\ Estadual do Paraná - UNESPAR, Campus de União da Vitória. Caixa Postal 241, CEP 84600-970, União da Vitória, PR, Brazil. 3 Laboratório de \\ Ecologia de Peixes e Invasões Biológicas. Universidade Estadual de Londrina, Centro de Ciências Biológicas, Departamento de Biologia Animal e \\ Vegetal, Rodovia Celso Garcia Cid, PR 445, Km 380, CEP 86.057-970 - Londrina, Paraná, Brazil \\ Corresponding author: Alan Deivid Pereira, alandeivid_bio@live.com
}

\begin{abstract}
Campos Gerais National Park lies within the Brazilian Atlantic Rainforest, a biodiversity hotspot and a priority for conservation. Current analysis, featuring a list of large and medium-sized mammal species in the park, was conducted between July 2013 and July 2014 and between May 2016 and April 2017. With a 780-hour sampling effort in active research and 157,516 hours in camera traps, 31 species of 17 families and 8 orders were recorded. Furthermore, $42 \%$ of recorded mammals in the park proved to be endangered species at state, national, or international levels. Two exotic and 1 domestic species were reported in the park. Results contribute towards an in-depth knowledge of the fauna in south Brazil and may help in further research work and management, complying with conservation proposals in the biodiversity of the Campos Gerais region in the state of Paraná, Brazil.
\end{abstract}

\section{Key words}

Atlantic Rainforest; conservation; inventories; Mixed Ombrophilous Forest; species richness; tropical forest.

Academic editor: Átilla Colombo Ferreguetti | Received 19 May 2018 | Accepted 7 August 2018 | Published 28 September 2018

Citation: Pereira AD, Bazilio S, Orsi LM (2018) Checklist of medium-sized to large mammals of Campos Gerais National Park, Paraná, Brazil. Check List 14 (5): 785-799. https://doi.org/10.15560/14.5.785

\section{Introduction}

The Brazilian Atlantic Rainforest Biome, which has only $12.4 \%$ of its original cover area, represented mostly by fragments less than 100 ha in area (SOS Mata Atlântica and INPA 2018), is a biodiversity hotspot and priority area for conservation (Myers et al. 2000). It is estimated that more than 298 mammal species are extant in the Atlantic Rainforest, with approximately 100 animals with an adult body mass of at least $1 \mathrm{~kg}$, or rather, medium-sized and large animals (Paglia et al. 2012, Reis et al. 2014).
Mammals have an important role in the maintenance and equilibrium of forest ecosystems (Miller et al. 2001, Magioli et al. 2015), with several ecological services. These comprise prey population control, plant pollination and seed dispersal, contributing towards the regeneration of forests (Terborgh et al. 1999, Galetti et al. 2015, Derhé et al. 2017). However, owing to anthropogenic forest fragmentation, modification of habitats, introduction of exotic species and other factors, several species of this group are endangered in many Brazilian states (MMA 2014, IUCN 2018). The above factors plus hunting 


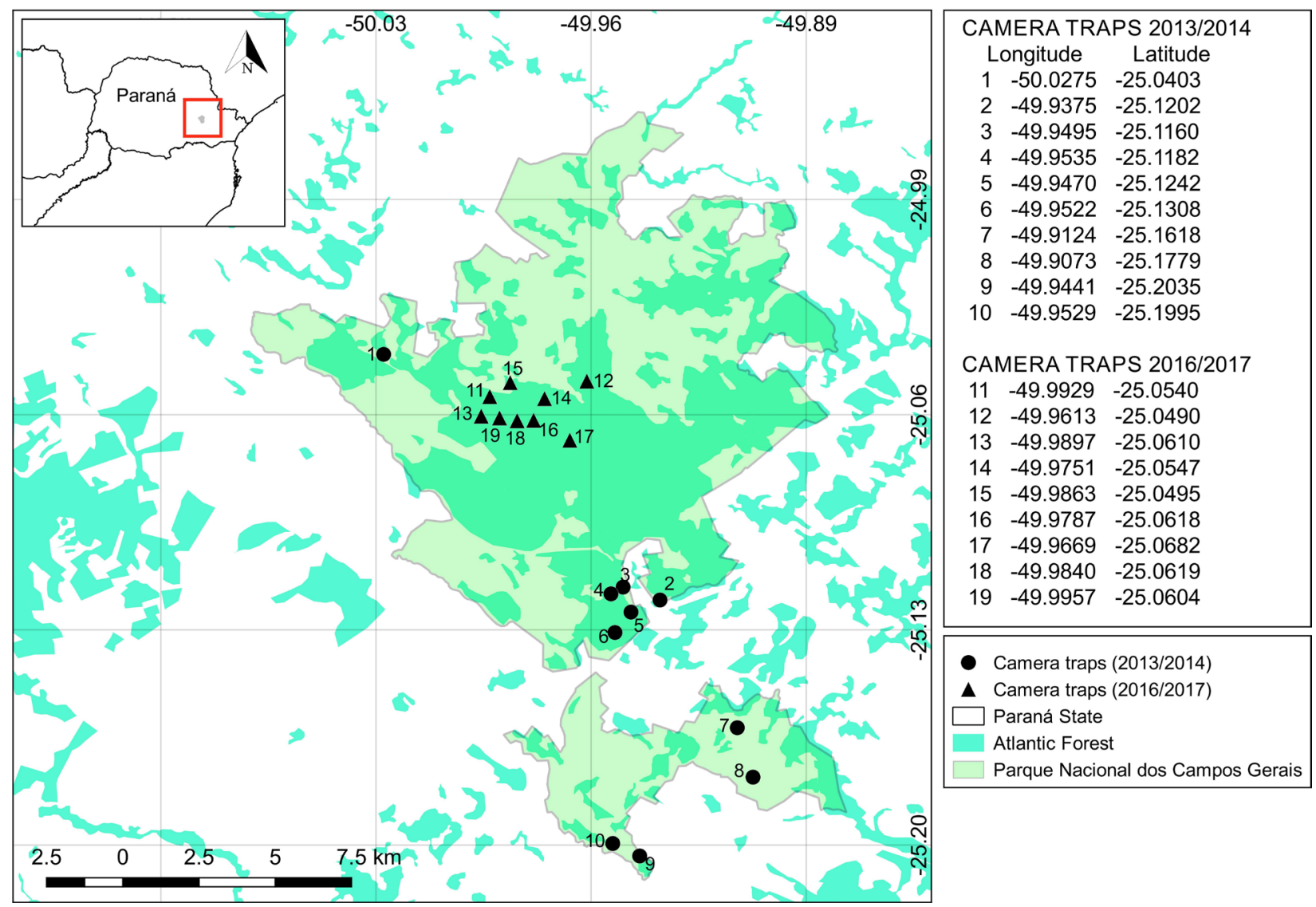

Figure 1. Map of the Parque Nacional dos Campos Gerais, state of Paraná, Brazil, with monitoring sites by camera traps during the 2013-2014 and 2015-2017 sampling periods.

activities (Oliveira and Cassaro 2006) lead to loss of biodiversity, which cause the near extinction of several species (Mazzolli 2005).

The establishment of conservation units comprises a type of action taken by the Brazilian government for the preservation of biodiversity (SNUC 2000). Conservation units have several aims, such as the protection of terrestrial and marine ecosystems, the safeguarding of endangered species at the regional and national levels and defending the region's flora and fauna. In fact, conservation should exist parallel to the aims of forest production (SNUC 2000). National Parks (PARNA in Portuguese) feature among the models of conservation units. In fact, the aim of PARNAs is to protect the nature, subsidizing the natural sciences, allowing for tourist visits, and preserving forest and biodiversity for future generations (SNUC 2000). The state of Paraná, Brazil, is currently responsible for 5 National Parks, namely Parque Nacional do Iguaçu, Parque Nacional do Superagui, Parque Nacional de Ilha Grande, Parque Nacional Saint-Hilaire/ Lange, and Parque Nacional dos Campos Gerais. The latter was the last to be established (Oliveira 2012).

Although the Parque Nacional dos Campos Gerais was established in 2006 to preserve remnants of the Mixed Ombrophilous Forest and native woods in the state of Parana (Oliveira 2012), no inventory of mediumsized and large mammals has been produced after 12 years. There is a knowledge gap for the Paraná Devonian
Escarpment, as the region is scientifically called.

Increasing changes in land use and occupation, and low representativeness of protected areas, rank the ecosystems of the Campos Gerais among the most endangered in the Brazil (Almeida and Moro 2007). Because crucial requirements for the development of conservation actions depend on basic knowledge of species and their distribution (Kasper et al. 2007), and the Campos Gerais study area lacks deep scientific information on biodiversity, especially of medium-sized and large mammals, the current analysis provides a list of medium-sized and large mammals for Parque Nacional dos Campos Gerais, Paraná, Brazil.

\section{Methods}

Study area. Parque Nacional dos Campos Gerais (hereafter PNCG), in the southern state of Paraná, Brazil, has an area of 21,298.91 hectares, partially covering areas in the municipalities of Ponta Grossa, Castro, and Carambeí. It lies on the Devonian Scarp region, with 2 sections on the first and second plateau of the Paraná $\left(25^{\circ} 03.754^{\prime}\right.$ $\mathrm{S}, 049^{\circ} 57.693^{\prime} \mathrm{W}$ and $25^{\circ} 09.897^{\prime} \mathrm{S}, 049^{\circ} 56.281^{\prime} \mathrm{W}$ ) (Oliveira 2012) (Fig. 1).

Yearly rainfall ranges between 100 and $300 \mathrm{~mm}$, with the mean temperature at $17.8^{\circ} \mathrm{C}$ (Maack 2017). Soils are constituted of acric red-yellow latosol and dystrophic haplic cambisol (Almeida and Moro 2007). Remnants 
are frequently represented by almost circular patches of forests (regionally called "capões" in Portuguese), gallery forests or mixed woodland, particularly on slopes or diabase dikes (Moro 2001). The association between the Araucaria pine-tree forest and fields form the region's typical landscape, combining significant forest areas and the last remnants of the Atlantic Rainforest (Maack 2017).

Sampling. Sampling occurred at 2 different stages, namely, between July 2013 and July 2014, (permit 37691-1 ICMBio for scientific activities) and between May 2016 and April 2017 (permit 53800-1 ICMBio), totaling more than 780 hours of search in approximately $815 \mathrm{~km}$ of trails and roads. The following methods were applied: (1) direct search for evidences using the active search method (Voss and Emmons 1996), which consists of walking at an average speed of $1 \mathrm{~km} / \mathrm{h}$, on trails and dirt roads, searching for direct (e.g., sightings, vocalizations) and indirect (e.g. footprints) evidences, and (2) camera traps.

The sand and clay soil in the park did not require sand plots to record footprints. Temporal independence of the samples or counting the number of recorded footprints by a single researcher at intervals of at least $300 \mathrm{~m}$ between the first footprint up to the next one, was avoided. Continuous sequences on the same road were avoided, following Pardini et al. (2004). Surveys were monthly, starting at 8:00 $\mathrm{h}$ and lasting for 4-6 hours, depending on the number of records. Footprints were identified in the field and photographed. They were based on measurements and print format, confirmed later by specific literature on the theme (e.g. Becker and Dalponte 2013, Reis et al. 2014).

Camera traps obtained information on nocturnal species and on those with difficult visualization, such as most medium-sized and large mammals (Srbek-Araujo and Chiarello 2013). Nineteen camera traps (Bushnell model) were distributed throughout the forest fragments, near water sprouts, on the treks and pathways of the park, taking into account the commonest trails used by species. Cameras were kept at a distance of at least $1 \mathrm{~km}$ and placed $50 \mathrm{~cm}$ above the ground on trees. The researchers also talked to local residents to complement information on their search on the species of the park. Camera traps were active during the 24 months of sampling, with a monthly change of memory cards and batteries during the study period. Sampling effort was equal to the number of camera traps multiplied by the number of sampling days (with 24 hours). An event was independent when there were (a) consecutive photographs by the same camera with an interval of at least 60 minutes and (b) non-consecutive photographs by the same camera (Srbek-Araujo and Chiarello 2013). Observations of species were opportunistically recorded in the study area to improve the species inventories obtained by camera-traps.

Species were identified by camera trap records and opportunistic photos based on specialized literature (e.g. Oliveira and Cassaro 2006, Reis et al. 2011, 2014). Felines were identified by body size, pelage, nose, eyes and tail characteristics (for small felines) and by size and shape of footprint (for Puma concolor Linnaeus, 1771) (Oliveira and Cassaro 2006).

All the species with an adult body mass equal of 1 $\mathrm{kg}$ or more were considered medium-sized and large mammals (Reis et al. 2011) and included in the list. Conservation status was obtained for each species within state, country and international context (BRASIL 2010, MMA 2014, IUCN 2018). Trophic guild classification followed Reis et al. (2014). The taxonomic nomenclature followed Paglia et al. (2012). Furthermore, the recent distinction between Leopardus guttulus (Hensel, 1872) and Leopardus tigrinus (Schreber, 1775) in southern and southeastern Brazil was acknowledged (Trigo et al. 2013). Patton et al. (2015) was consulted for xenarthrans and rodents.

Data analysis. Records of footprints, camera traps and visual searches together made up the data for the list. Footprint records and photographs were separated to estimate expected richness according to different methodologies. By separating footprint and camera-trap records, 2 rarefaction curves of mammal species were drawn, with 1,000 randomizations and first-order jackknife (Jackknife 1) estimator by EstimateS 8.2 (Colwell 2009).

\section{Results}

We recorded 31 medium-sized and large mammal species, distributed in 17 families and 8 orders (Figs 2-30; Table 1). Twenty-four species were recorded in 2013-2014 sampling, to which 7 additional species were added from the 2016-2017 survyes (Table 1). Twelve species belonged to the order Carnivora and 5 species from orders Rodentia and Cetartiodactyla, followed by the orders Cingulata, Didelphimorphia, Pilosa, Primates and Lagomorpha, which had 2 species each (Table 1).

Species were distributed in 5 trophic guilds, or rather, $45.16 \%$ of the species were omnivorous, followed by carnivores, herbivores and frugivores (16.13\% each) and insectivores $(6.45 \%)$ (Table 1$)$. Among the species recorded in current study, $11(35.4 \%)$ were threatened at the state level; $8(25.8 \%)$ at the national level; 6 species $(19.3 \%)$ at the international level (Table 1). There were also 2 exotic species (Lepus europaeus (Pallas, 1778) and Sus scrofa Linnaeus, 1758) and a domestic one (Canis lupus familiaris) present in PNCG.

Following the methodology in the current study, 54 footprint registrations were observed, with 10 species identified. Estimated richness was $12.7 \pm 1.37$ species (Fig. 31). Furthermore, 16 species were recorded by opportunistic observations and 2 species of primates were identified by vocalization (Table 1 ).

Camera-trap sampling efforts from the 2013/2014 and 2016/2017 campaigns totaled 80,016 and 77,500 camera hours, respectively. Total sampling effort amounted to 


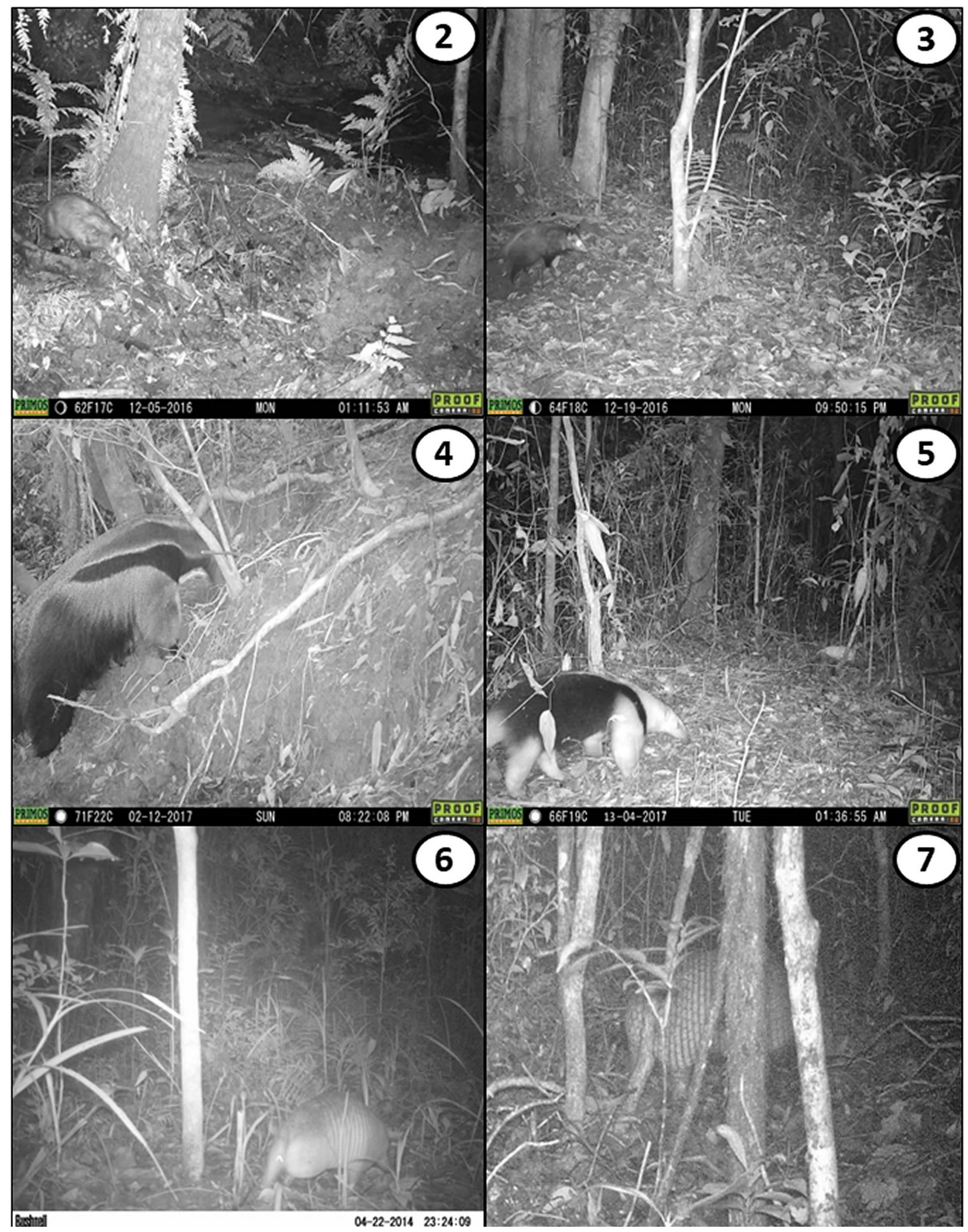

Figures 2-7. Photographs of the medium-sized and large mammal species recorded in the Parque Nacional dos Campos Gerais, state of Paraná, Brazil. 2. Didelphis albiventris. 3. Didelphis aurita. 4. Myrmecophaga tridactyla. 5. Tamandua tetradactyla. 6. Dasypus novemcinctus.

157,516 camera trap hours and 26 recorded species with an estimated richness of $35 \pm 1.56$ (Fig. 31).

\section{Annotated list}

Didelphimorphia

Didelphidae
Didelphis albiventris Lund, 1840

Figure 2

Records. First record was in July 09, 2013, camera trap $6\left(25^{\circ} 07.27^{\prime} \mathrm{S}, 049^{\circ} 56.49^{\prime} \mathrm{W}\right)$ and subsequently in the monitoring sites (camera traps 1, 2, 3, 4, 11, 12, 13, 14, 15, 16, 17, 19 and 19, see Fig. 1 for coordinates). 


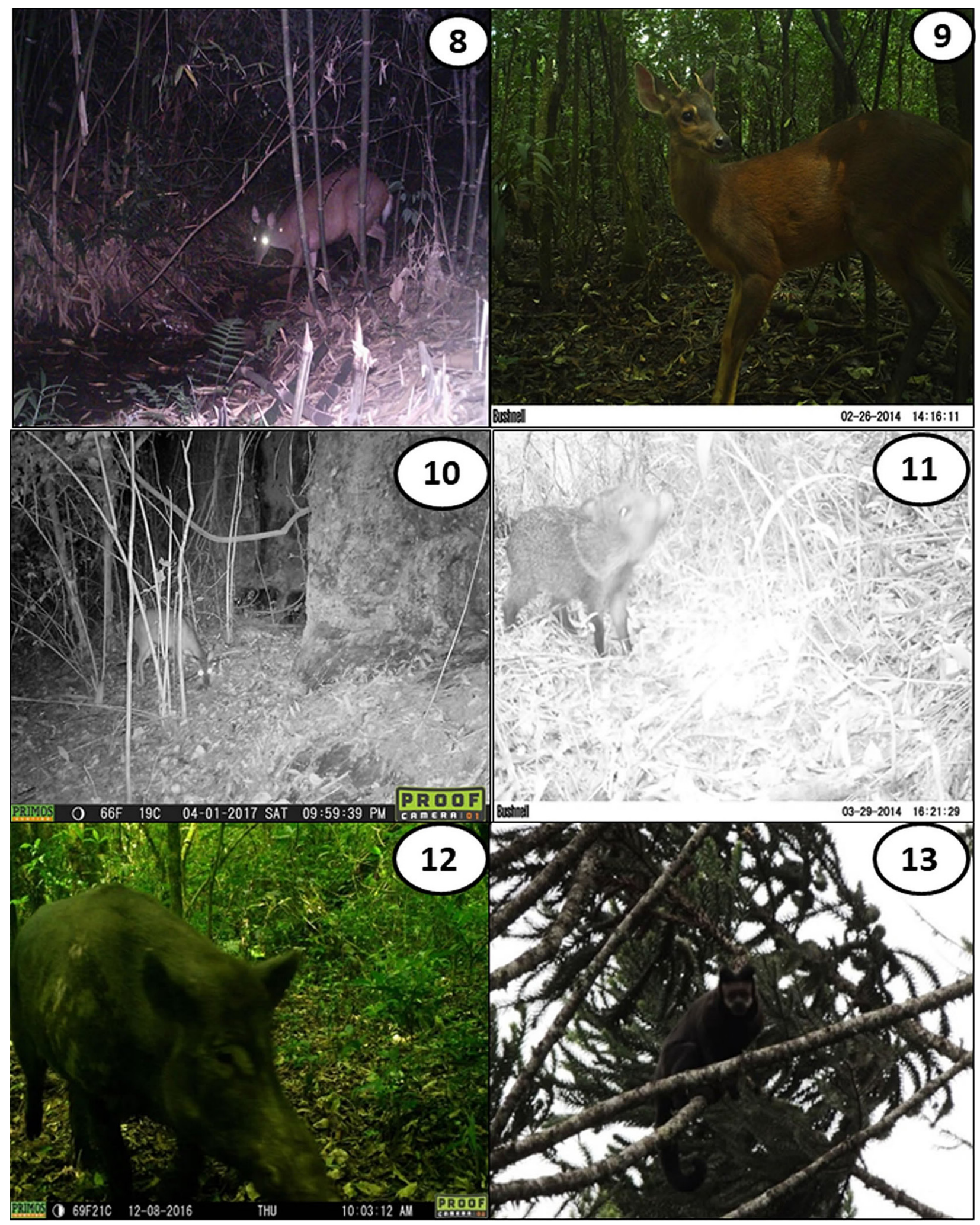

Figures 8-13. Photographs of the medium-sized and large mammal species recorded in the Parque Nacional dos Campos Gerais, state of Paraná, Brazil. 8. Mazama gouazoubira. 9. Mazama americana. 10. Mazama nana. 11. Pecari tajacu. 12. Sus scrofa.13. Sapajus nigritus.

Identification. Didelphis albiventris has totally white or black-tipped ears with whitish tips and no hair; face with yellowish-white coat with black spots around the eyes and a conspicuous stain on the central region of the head.

Didelphis aurita (Wied-Neuwied, 1826) Figure 3
Records. First record was in August 06, 2013, camera trap $3\left(25^{\circ} 03.59^{\prime} \mathrm{S}, 049^{\circ} 57.26^{\prime} \mathrm{W}\right)$ and subsequently in the monitoring sites (camera traps 1, 2, 9 and 11, see Fig. 1 for coordinates).

Identification. Didelphis aurita has black hairless ears; variable head color, ranging from black to yellow. Black spots on the eyes and dark coloration on the dorsal region. 


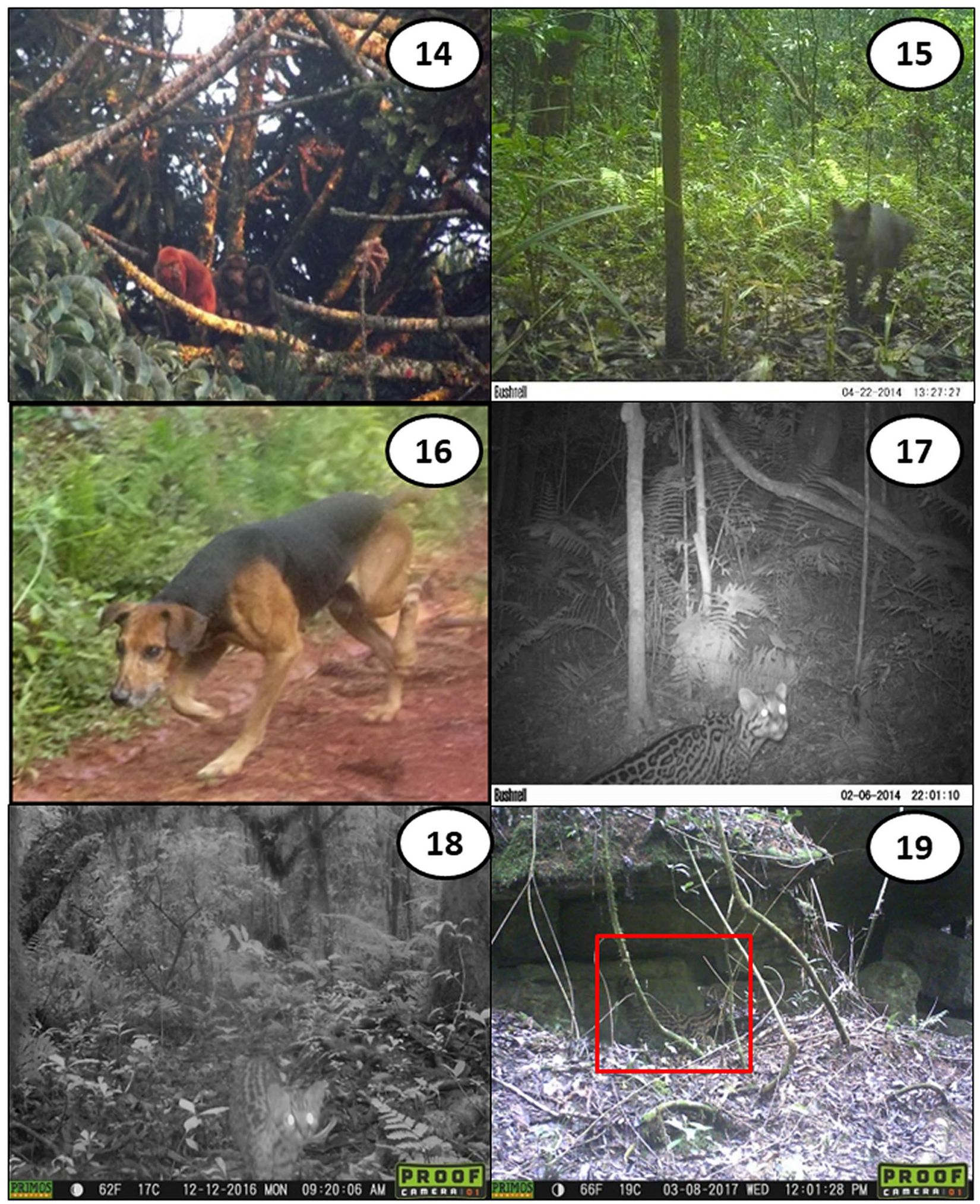

Figures 14-19. Photographs of the medium-sized and large mammal species recorded in the Parque Nacional dos Campos Gerais, state of Paraná, Brazil. 14. Alouatta guariba clamitans.15. Cerdocyon thous. 16. Canis lupus familiaris. 17. Leopardus pardalis. 18. Leopardus guttulus.

Pilosa

Mymercophagidae

Myrmecophaga tridactyla Linnaeus, 1758 Figure 4

Records. First record was in August 08, 2016, camera trap $18\left(25^{\circ} 03.37^{\prime} \mathrm{S}, 049^{\circ} 59.44^{\prime} \mathrm{W}\right)$ and subsequently in the same monitoring site.
Identification. Two species of anteaters are known in the region of PNCG, with each having different body size and color pattern of pelage. Myrmecophaga tridactyla is a large species and weighs up to $45 \mathrm{~kg}$. It has small ears and small eyes, long snout and an extremely long tongue; the thick pelage varies from dark gray and black, but with the paws white paws and some black bands at the top. The tail is robust and covered by hair. 


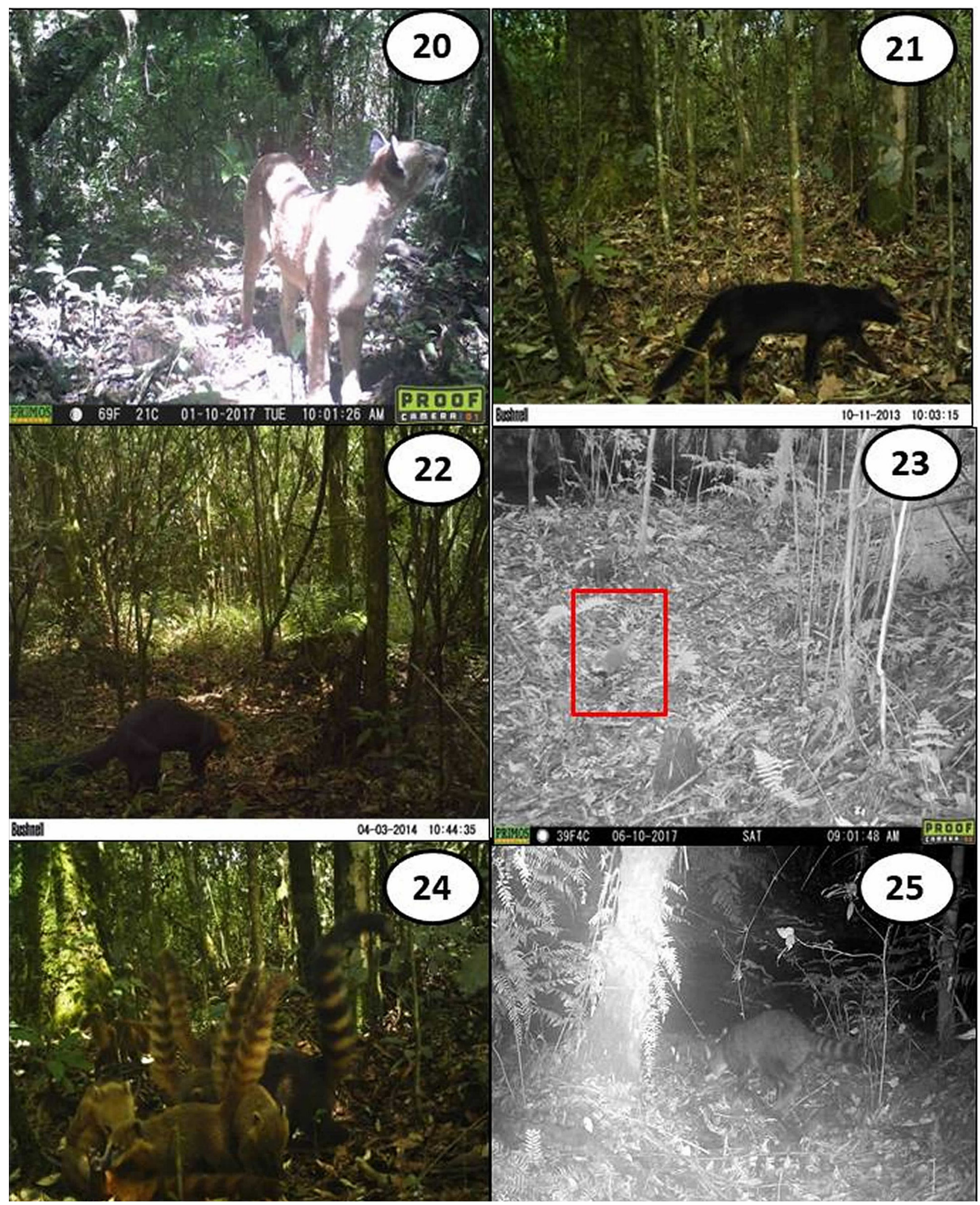

Figures 20-25. Photographs of the medium-sized and large mammal species recorded in the Parque Nacional dos Campos Gerais, state of Paraná, Brazil. 20. Puma concolor. 21. Puma yagouaroundi. 22. Eira barbara. 23. Galictis cuja. 24. Nasua nasua. 25. Procyon cancrivorus.

Tamandua tetradactyla (Linnaeus, 1758) Figure 5

Records. First record was in August 08, 2016, camera trap $11\left(25^{\circ} 03.04^{\prime} \mathrm{S}, 049^{\circ} 59.33^{\prime} \mathrm{W}\right)$ and subsequently in the same monitoring site.

Identification. This is a smaller species, with an elongated snout and tongue (Fig. 5) and short, dense and pale-yellow pelage. There are 2 black stripes on the scapular region towards the posterior region of the animal.

Cingulata

Dasypodidae

Dasypus novemcinctus Linnaeus, 1758

Figure 6 

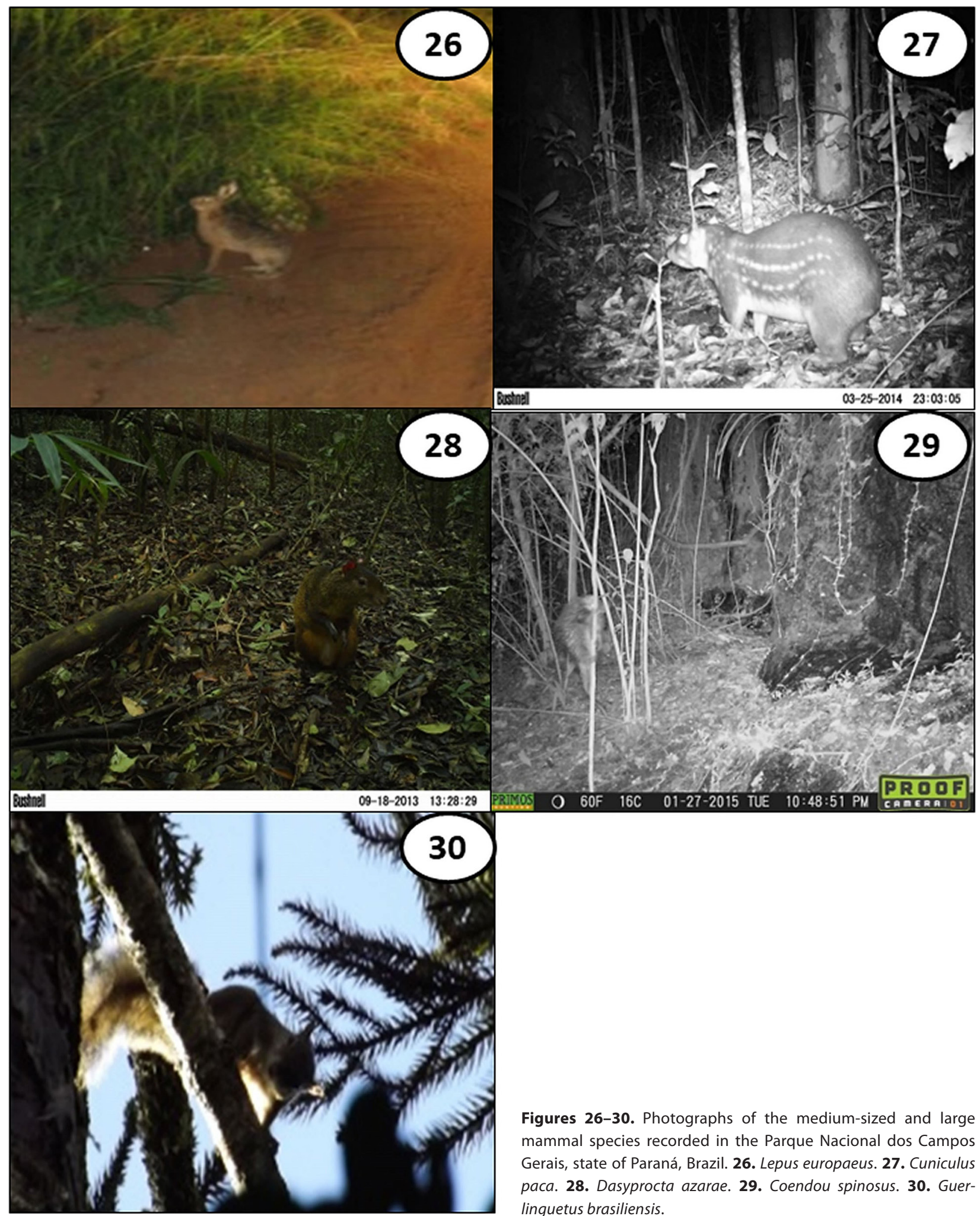

Figures 26-30. Photographs of the medium-sized and large mammal species recorded in the Parque Nacional dos Campos Gerais, state of Paraná, Brazil. 26. Lepus europaeus. 27. Cuniculus paca. 28. Dasyprocta azarae. 29. Coendou spinosus. 30. Guerlinguetus brasiliensis.

Records. First record was in July 10, 2013, camera trap $1\left(25^{\circ} 02.25^{\prime} \mathrm{S}, 050^{\circ} 01.39^{\prime} \mathrm{W}\right)$ and subsequently in the monitoring sites (camera traps 2, 3, 4, 7 and 11, see Fig. 1 for coordinates).

Identification. The species differentiation was based on characteristics of carapace that covers the body of the animals. Species-based variations exist in the moving bands located in the median region of the body. Dasypus novemcinctus has long, pointed ears, about $50 \%$ of the length of the head, which has a pinkish-yellow plaque (Fig. 6); dark carapace, with yellowish dermal shields. Although 9 mobile bands are extant, the number may range from 8 to 11 .

\section{Euphractus sexcinctus Linnaeus, 1758}

Figure 7 
Table 1. List of land medium-sized and large mammal species at the Parque Nacional dos Campos Gerais, Brazil. Record method; Footprint (F), Visualization (VI), Camera traps (CT), Vocalization (VO). Conservation status by (IUCN), Brazilian List of Threatened Species (BR), Paraná state List of Threatened Species (PR). Data Deficient (DD), Endangered (EN), Least Concern (LC), Not evaluated (NE), Near Threatened (NT), Vulnerable (VU) and Critically Endangered (CR). Species added in 2016 to 2017 (+). Exotic species (*). Small species (**).

\begin{tabular}{|c|c|c|c|c|c|}
\hline \multirow{2}{*}{ Taxon } & \multirow{2}{*}{ Record } & \multirow{2}{*}{ Trophic guild } & \multicolumn{3}{|c|}{ Conservation status } \\
\hline & & & IUCN & BR & PR \\
\hline \multicolumn{6}{|l|}{$\begin{array}{l}\text { Didelphimorphia } \\
\text { Didelphidae }\end{array}$} \\
\hline Didelphis albiventris Lund, 1840 & $\mathrm{VI}-\mathrm{CT}$ & Omnivore & LC & $\mathrm{NE}$ & LC \\
\hline Didelphis aurita (Wied-Neuwied, 1826) & CT & Omnivore & LC & $\mathrm{NE}$ & LC \\
\hline \multicolumn{6}{|l|}{$\begin{array}{l}\text { Pilosa } \\
\text { Mymercophagidae }\end{array}$} \\
\hline Myrmecophaga tridactyla Linnaeus, $1758^{+}$ & CT & Insectivore & VU & VU & $C R$ \\
\hline Tamandua tetradactyla (Linnaeus, 1758) $^{+}$ & CT & Insectivore & LC & $\mathrm{NE}$ & LC \\
\hline \multicolumn{6}{|l|}{$\begin{array}{l}\text { Cingulata } \\
\text { Dasypodidae }\end{array}$} \\
\hline Dasypus novemcinctus Linnaeus, 1758 & CT & Omnivore & LC & $\mathrm{NE}$ & LC \\
\hline Euphractus sexcinctus Linnaeus, 1758 & CT & Omnivore & LC & $\mathrm{NE}$ & LC \\
\hline \multicolumn{6}{|l|}{$\begin{array}{l}\text { Cetartiodactyla } \\
\text { Cervidae }\end{array}$} \\
\hline Mazama americana (Erxleben, 1777) & $\mathrm{VI}-\mathrm{CT}$ & Herbivore & DD & $\mathrm{NE}$ & VU \\
\hline Mazama gouazoubira (G. Fischer, 1814) & $\mathrm{F}-\mathrm{Vl}-\mathrm{CT}$ & Herbivore & Vu & VU & VU \\
\hline Mazama nana (Hensel,1872)+ & CT & Herbivore & LC & $\mathrm{NE}$ & LC \\
\hline \multicolumn{6}{|l|}{ Tayassuidae } \\
\hline Pecari tajacu (Linnaeus, 1758) & CT & Omnivore & LC & LC & VU \\
\hline \multicolumn{6}{|l|}{ Suidae } \\
\hline Sus scrofa Linnaeus, $1758^{*+}$ & $\mathrm{VI}-\mathrm{CT}$ & Omnivore & LC & $\mathrm{NE}$ & $\mathrm{NE}$ \\
\hline \multicolumn{6}{|l|}{$\begin{array}{l}\text { Primates } \\
\text { Cebidae }\end{array}$} \\
\hline Sapajus nigritus Goldfuss, 1809 & VIIVO & Omnivore & NT & $\mathrm{NE}$ & DD \\
\hline \multicolumn{6}{|l|}{ Atelidae } \\
\hline Alouatta guariba clamitans (Humboldt, 1812) & VI-VO & Omnivore & LC & VU & NT \\
\hline \multicolumn{6}{|l|}{$\begin{array}{l}\text { Carnivora } \\
\text { Canidae }\end{array}$} \\
\hline Canis lupus familiaris Linnaeus $1758^{*}$ & $\mathrm{~F}-\mathrm{Vl}-\mathrm{CT}$ & Omnivore & $\mathrm{NE}$ & $\mathrm{NE}$ & NE \\
\hline Cerdocyon thous (Linnaeus, 1766) & $\mathrm{F}-\mathrm{VI}-\mathrm{CT}$ & Omnivore & LC & $\mathrm{NE}$ & LC \\
\hline Chrysocyon brachyurus (Illiger, 1815)+ & $\mathrm{F}-\mathrm{VI}$ & Omnivore & NT & VU & vU \\
\hline \multicolumn{6}{|l|}{ Felidae } \\
\hline Leopardus pardalis (Linnaeus, 1758) & $\mathrm{F}-\mathrm{CT}$ & Carnivore & LC & $\mathrm{NE}$ & VU \\
\hline Leopardus guttulus Hensel, 1872 & Ст & Carnivore & vu & vu & vu \\
\hline Leopardus wiedii (Schinz, 1821) & CT & Carnivore & NT & VU & VU \\
\hline Puma concolor (Linnaeus, 1771) & $\mathrm{F}-\mathrm{VI}-\mathrm{CT}$ & Carnivore & LC & VU & Vu \\
\hline Puma yagouaroundi (É. Geoffroy Saint-Hilaire, 1803) & $\mathrm{VI}-\mathrm{CT}$ & Carnivore & LC & VU & DD \\
\hline \multicolumn{6}{|l|}{ Mustelidae } \\
\hline Eira barbara (Linnaeus, 1758) & CT & Omnivore & LC & $\mathrm{NE}$ & LC \\
\hline Galictis cuja (Molina, 1782)+ & CT & Omnivore & LC & $\mathrm{NE}$ & NE \\
\hline \multicolumn{6}{|l|}{ Procyonidae } \\
\hline Nasua nasua (Linnaeus, 1766) & $\mathrm{VI}-\mathrm{CT}$ & Omnivore & LC & NE & LC \\
\hline Procyon cancrivorus (G. [Baron] Cuvier,1798) & $\mathrm{F}-\mathrm{CT}$ & Omnivore & LC & NE & LC \\
\hline \multicolumn{6}{|l|}{$\begin{array}{l}\text { Lagomorpha } \\
\text { Leporidae }\end{array}$} \\
\hline Lepus europaeus Pallas, $1778^{*}$ & $\mathrm{~F}-\mathrm{VI}$ & Herbivore & LC & $\mathrm{NE}$ & NE \\
\hline \multicolumn{6}{|l|}{$\begin{array}{l}\text { Rodentia } \\
\text { Caviidae }\end{array}$} \\
\hline Hydrochoerus hydrochaeris (Linnaeus, 1766) & $\mathrm{F}-\mathrm{VI}$ & Herbivore & LC & $\mathrm{NE}$ & LC \\
\hline \multicolumn{6}{|l|}{ Cuniculidae } \\
\hline Cuniculus paca (Linnaeus, 1766) & $\mathrm{F}-\mathrm{CT}$ & Frugivore & LC & $\mathrm{NE}$ & EN \\
\hline \multicolumn{6}{|l|}{ Dasyproctidae } \\
\hline Dasyprocta azarae Lichtenstein, 1823 & СT & Frugivore & DD & $\mathrm{NE}$ & LC \\
\hline \multicolumn{6}{|l|}{ Erethizontidae } \\
\hline Coendou spinosus (F. Cuvier, 1823)+ & $\mathrm{VI}-\mathrm{CT}$ & Frugivore & LC & $\mathrm{NE}$ & LC \\
\hline Guerlinguetus brasiliensis $(G m e l i n, 1788)^{* * *}$ & $\mathrm{VI}-\mathrm{CT}$ & Frugivore & LC & $\mathrm{NE}$ & LC \\
\hline
\end{tabular}




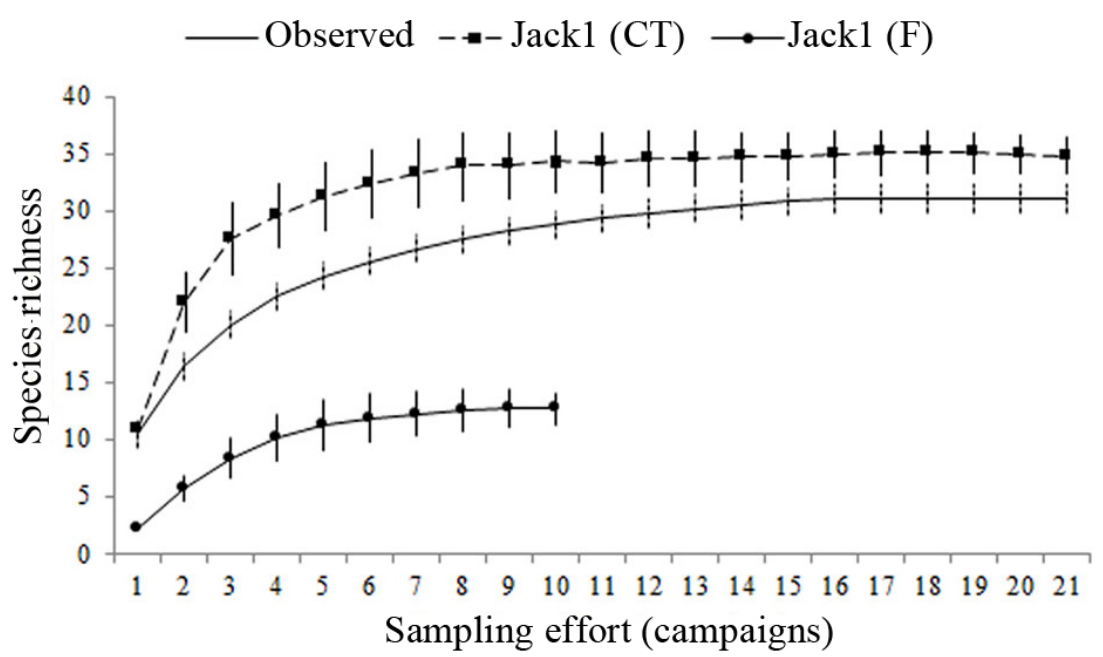

Figure 31. The rarefaction curve (observed and estimates by jackknife 1) of mammal species registered by identification of footprints and trap cameras. Vertical bars represent standard deviation. CT: Camera trap; F: footprints.

Records. Record was in May 01, 2014 camera trap 1 $\left(25^{\circ} 02.25^{\prime} \mathrm{S}, 050^{\circ} 01.39^{\prime} \mathrm{W}\right)$.

Identification. Euphractus sexcinctus has 6 to 8 moving bands on the back of the carapace; there are 2 to 4 orifices in the region of the pelvic girdle near the base of the tail.

Cetartiodactyla

Cervidae

\section{Mazama americana (Erxleben, 1777)}

Figure 8

Records. First record was in July 26, 2013, camera trap $6\left(25^{\circ} 07.51^{\prime} \mathrm{S}, 049^{\circ} 57.08^{\prime} \mathrm{W}\right)$ and subsequently in the monitoring sites (camera traps 5 and 11, see Fig. 1 for coordinates).

Identification. The identification of species of the genus Cervidae was based on differences in body size, coat color and distribution area. Mazama americana is the largest species of the genus in Brazil, medium to moderately large, a factor that helps in the differentiation of the species. It has a reddish coloration, with white spots below the tail, inner face of limbs and ears.

\section{Mazama gouazoubira (G. Fischer, 1814)}

Figure 9

Records. First record was in July 30, 2013, camera trap $1\left(25^{\circ} 02.25^{\prime} \mathrm{S}, 050^{\circ} 01.39^{\prime} \mathrm{W}\right)$ and subsequently in the monitoring sites (camera traps 2, 3, 5, 6, 7, 14 and 15, see Fig. 1 for coordinates).

Identification. Mazama gouazoubira is a smaller species when compared to $M$. americana, weighing between 17 and $23 \mathrm{~kg}$. The coloration is quite varied, with brown, gray and reddish variations.

\section{Mazama nana (Hensel, 1872)}

Figure 10

Records. Record was in May 17, 2016 camera trap 15 $\left(25^{\circ} 03.36^{\prime} \mathrm{S}, 049^{\circ} 59.44^{\prime} \mathrm{W}\right)$.
Identification. Mazama nana is the smallest species, with weight not exceeding $15 \mathrm{~kg}$. The skin is characterized by an intense bright reddish hue.

Cetartiodactyla

Tayassuidae

\section{Pecari tajacu (Linnaeus, 1758)}

Figure 11

Records. First record was in July 31, 2013, camera trap $6\left(25^{\circ} 07.51^{\prime} \mathrm{S}, 049^{\circ} 57.08^{\prime} \mathrm{W}\right)$ and subsequently in the monitoring sites (camera traps 1, 2, 4, 7, 9, 10, 11, 12, 13, 14, 15, 16, 17, 18 and 19, see Fig. 1 for coordinates).

Identification. The identification of the Brazilian native pig Pecari tajacu (Linnaeus, 1758) was based on pelage characteristics. A collar formed by slightly clear hair may be observed around its neck, differentiating the species from other native pigs.

Suidae

\section{Sus scrofa Linnaeus, 1758}

Figure 12

Records. First record was on May 5, 2013, camera trap $16\left(25^{\circ} 03.37^{\prime} \mathrm{S}, 049^{\circ} 58.43^{\prime} \mathrm{W}\right)$ and subsequently in the monitoring sites (camera traps 1, 2, 4, 7, 9, 10, 11, 12, $13,14,15,16,17,18$ and 19, see Fig. 1 for coordinates).

Identification. Sus scrofa is a swine native to Europe, Africa and Asia. Featuring great individual variations in body size and pelage color, it was introduced in the area under analysis. Although S. scrofa may be confused with $P$. tajacu, the species is usually larger.

\section{Primates}

Cebidae

\section{Sapajus nigritus (Goldfuss, 1809)}

Figure 13 
Records. First record was in May 17, 2014, monitoring site $3\left(25^{\circ} 03.59^{\prime} \mathrm{S}, 049^{\circ} 57.26^{\prime} \mathrm{W}\right) 12$ individuals were recorded by opportunistic observations and subsequently in the monitoring sites 1, 2 and 11 (see Fig. 1 for coordinates).

Identification. Sapajus nigritus has a generally black coloration, even though hue may vary by region. The face is pigmented, usually light brown, and the coat of the head is rather blacker.

Atelidae

\section{Alouatta guariba clamitans Cabrera, 1940}

Figure 14

Records. Record was in March 16, 2014, monitoring site $9\left(25^{\circ} 12.12^{\prime} \mathrm{S}, 049^{\circ} 56.39^{\prime} \mathrm{W}\right) 7$ individuals were recorded by opportunistic observations.

Identification. Alouatta guariba clamitans is larger than S. nigritus. Males have a uniform reddish color, while the color of females ranges from blackish to dark-brown. The face is pigmented in darker shades of gray.

Carnivora

Canidae

\section{Cerdocyon thous (Linnaeus 1766)}

Figure 15

Records. First record was in October 12, 2013, camera trap $3\left(25^{\circ} 03.59^{\prime} \mathrm{S}, 049^{\circ} 57.26^{\prime} \mathrm{W}\right)$ and subsequently in the monitoring sites (camera traps 1, 2, see Fig. 1 for coordinates).

Identification. Cerdocyon thous was identified by its small size, and short, dense coat with a gray to brown hue.

\section{Chrysocyon brachyurus (Illiger, 1815)}

Records. Record was in May 12, 2016, monitoring site $11\left(25^{\circ} 03.04^{\prime} \mathrm{S}, 049^{\circ} 59.33^{\prime} \mathrm{W}\right) 1$ individual was recorded by opportunistic observations.

Identification. Chrysocyon brachyurus is larger, with a small head in relation to body, small ears and tapering muzzle, with a general brown-orange coloration at the tip of the muzzle and end of the black limbs. The latter was only identified through footprints and personal reports of residents of farms near the PNCG.

\section{Canis lupus familiaris Linnaeus 1758}

Figure 16

Records. First record was in July 13, 2013, camera trap trap $1\left(25^{\circ} 02.25^{\prime} \mathrm{S}, 050^{\circ} 01.39^{\prime} \mathrm{W}\right)$ and subsequently in the monitoring sites (camera traps 3, 5, 7, 10, 12, 13, 14, 15, 16 and 19, see Fig. 1 for coordinates).

Felidae
Figure 17

Records. First record was in October 14, 2013, camera trap $3\left(25^{\circ} 03.59^{\prime} \mathrm{S}, 049^{\circ} 57.26^{\prime} \mathrm{W}\right)$ and subsequently in the monitoring sites (camera traps 5, 12, 13, 15 and 19, see Fig. 1 for coordinates).

Identification. Five feline species were identified, based on patterns of body size and pelage. Leopardus pardalis was identified by its large body size, elongated rosettes pattern on the side of the body and a relatively smaller tail, when compared with other Leopardus species.

\section{Leopardus guttulus (Hensel, 1872) \\ Figure 18}

Records. First record was in January 28, 2014, camera trap $6\left(25^{\circ} 07.51^{\prime} \mathrm{S}, 049^{\circ} 57.08^{\prime} \mathrm{W}\right)$ and subsequently in the monitoring sites (camera traps 5, 13, 14, 15, 17 and 18, see Fig. 1 for coordinates).

Identification. Leopardus guttulus was identified by its relatively smaller tail with narrow rings, pink nose and pattern of circular shapes and eyespots on the sides of the body that differentiated the species from Leopardus wiedii.

\section{Leopardus wiedii (Schinz, 1821) \\ Figure 19}

Records. First record was in July 29, 2013, camera trap $1\left(25^{\circ} 02.25^{\prime} \mathrm{S}, 050^{\circ} 01.39^{\prime} \mathrm{W}\right)$ and subsequently in the monitoring sites (camera traps 3, 4, 5, 9 and 12, see Fig. 1 for coordinates).

Identification. Leopardus wiedii is characterized by a long tail, large eyes, protruding muzzle and large paws.

\section{Puma concolor (Linnaeus, 1771) \\ Figure 20}

Records. First record was in December 09, 2013, camera trap $2\left(25^{\circ} 08.02^{\prime} \mathrm{S}, 049^{\circ} 56.17^{\prime} \mathrm{W}\right)$ and subsequently in the monitoring sites (camera traps 3,11, 13, 14, 15, and 16, see Fig. 1 for coordinates).

Identification. Puma concolor is distinguishable by its short and uniform coat of brown color, ranging from light to reddish tones.

\section{Puma yagouaroundi (É. Geoffroy Saint-Hilaire, 1803) Figure 21}

Records. First record was in October 11, 2013, camera trap $5\left(25^{\circ} 07.27^{\prime} \mathrm{S}, 049^{\circ} 56.49^{\prime} \mathrm{W}\right)$ and subsequently in the monitoring sites (camera trap 7, see Fig. 1 for coordinates).

Identification. Puma yagouaroundi was identified by its monochromatic long body and tail.

Mustelidae

Eira barbara (Linnaeus, 1758) 
Figure 22

Records. First record was in July 17, 2013, camera trap $3\left(25^{\circ} 03.59^{\prime} \mathrm{S}, 049^{\circ} 57.26^{\prime} \mathrm{W}\right)$ and subsequently in the monitoring sites (camera traps 1, 4, 5, 12, 13, 15, 16, 18 and 19, see Fig. 1 for coordinates).

Identification. Two mustelids were registered in the PNCG. The identification of these animals was based on the pattern of the 2 species, namely, long body, short limbs and long tail. In the case of Eira barbara the color of the coat is dark brown throughout the entire body, with a lighter brown for head and neck, with regional variations.

\section{Galictis cuja (Molina, 1782)}

Figure 23

Records. First record was in May 03, 2017, camera trap $18\left(25^{\circ} 03.37^{\prime} \mathrm{S}, 049^{\circ} 59.44^{\prime} \mathrm{W}\right)$ and subsequently in the monitoring site 11 (see Fig. 1 for coordinates).

Identification. Galictis cuja is smaller in size than E. barbara; paws, belly, throat and face are black, with a yellowish back.

Procyonidae

\section{Nasua nasua (Linnaeus, 1766)}

Figure 24

Records. First record was in July 13, 2013, camera trap $1\left(25^{\circ} 02.25^{\prime} \mathrm{S}, 050^{\circ} 01.39^{\prime} \mathrm{W}\right)$ and subsequently in the monitoring sites (camera traps 2, 3, 4, 5, 6, 12, 13, and 15, see Fig. 1 for coordinates).

Identification. Two species of the family Procyonidae were registered. Nasua nasua, an exclusive species of South America, has an enlarged head tapering into a narrow and prolonged pointed snout. Coloration varies according to group, although the general pattern ranges between light and dark brown, with a generally striped tail.

\section{Procyon cancrivorus (G. Cuvier, 1798)}

Figure 25

Records. First record was in August 23, 2013, camera trap $3\left(25^{\circ} 03.59^{\prime} \mathrm{S}, 049^{\circ} 57.26^{\prime} \mathrm{W}\right)$ and subsequently in the monitoring sites (camera traps 6 and 18, see Fig. 1 for coordinates).

Identification. Procyon cancrivorus is easily identified by its black mask that descends from the eyes to the base of the mandible; its tail is characterized by several dark rings.

Lagomorpha

Leporidae

Lepus europaeus (Pallas, 1778)

Figure 26

Records. First record was in October 07, 2013, monitor- ing site $3\left(25^{\circ} 03.59^{\prime} \mathrm{S}, 049^{\circ} 57.26^{\prime} \mathrm{W}\right)$ individuals were recorded by opportunistic observations and subsequently in the monitoring sites 7, 8 and 18 (see Fig. 1 for coordinates).

Identification. Lepus europaeus is a species of European origin introduced in South America. It is larger in size than the native Sylvilagus brasiliensis (Linnaeus, 1758), with long ears and legs; general brownish gray color on the upper parts and of a somewhat lighter hue on the lower part. The above characteristics distinguish the hair of $S$. brasiliensis.

Rodentia

Caviidae

\section{Hydrochoerus hydrochaeris (Linnaeus, 1766)}

Records. Record was in November 29, 2013, monitoring site $7\left(25^{\circ} 09.42^{\prime} \mathrm{S}, 049^{\circ} 59.44^{\prime} \mathrm{W}\right)$.

Identification. Hydrochoerus hydrochaeris is the largest rodent in the world, easily identifiable due to the shape of the head with short ears and hue ranging between reddish to grayish brown. The species was recorded based on the analysis of footprints and opportunistic observations (Table 1)

Cuniculidae

\section{Cuniculus paca (Linnaeus, 1766)}

Figure 27

Records. First record was in July 12, 2013, camera trap $5\left(25^{\circ} 07.27^{\prime} \mathrm{S}, 049^{\circ} 56.49^{\prime} \mathrm{W}\right)$ and subsequently in the monitoring sites (camera traps 1, 2, 3, 6, 7, 8, 9, 11, 12, 13, 17, 18 and 19, see Fig. 1 for coordinates).

Identification. Cuniculus paca is a medium-sized rodent. Identification of the species was based on the pattern of the coat, ranging between brownish-red and dark brown, with a pattern of whitish rounded spots in longitudinal lines.

Dasyproctidae

\section{Dasyprocta azarae Lichtenstein, 1823}

Figure 28

Records. First record was in July 12, 2013, camera trap $5\left(25^{\circ} 07.27^{\prime} \mathrm{S}, 049^{\circ} 56.49^{\prime} \mathrm{W}\right)$ and subsequently in the all monitoring sites (see Fig. 1 for coordinates).

Identification. Dasyprocta azarae is a large orangebrown rodent with a rounded back and long skinny legs. Although 9 species of the genus Dasyprocta have been described for Brazil, D. azarae is the only species with a record of occurrences for the state of Paraná.

Erethizontidae

Coendou spinosus (F. Cuvier, 1823)

Figure 29 
Records. Record was in May 22, 2016 camera trap 12 $\left(25^{\circ} 02.55^{\prime} \mathrm{S}, 049^{\circ} 57.41^{\prime} \mathrm{W}\right)$ and by opportunistic observations in the same monitoring site.

Identification. Coendou spinosus was identified by coat and body shape. The coat is formed by a mixture of rigid, aculeiform (cylindrical 'spines') hairs and finer hairs. The former are longer than the latter ones. Coloration varies from yellowish to dark brown at the back.

\section{Sciuridae}

\section{Guerlinguetus brasiliensis (Gmelin, 1788)} Figure 30

Records. First record was in February 02, 2014, camera trap $5\left(25^{\circ} 07.27^{\prime} \mathrm{S}, 049^{\circ} 56.49^{\prime} \mathrm{W}\right)$ and subsequently 2 individuals were recorded by opportunistic observations in the monitoring sites 1 and 7 (see Fig. 1 for coordinates).

Identification. The squirrel Guerlinguetus brasiliensis may be included among the native species. Although small in size, it is easily identifiable through photographs. The species is an average sized squirrel with occurrences recorded in the Atlantic Rainforest. It is distinguished from other squirrels due to its intermediate body size and such characteristics as voluminous tail, longer than or equal to the body.

\section{Discussion}

Because Parque Nacional dos Campos Gerais has the largest phytophysionomy area of the Campos Gerais in Paraná (Maack 2017), it is highly important for the conservation of biodiversity. In fact, it harbors endemic and threatened species within its borders (Oliveira 2012). Species richness recorded by us corresponds to $56 \%$ of all medium-sized and large mammals with current occurrence for the state of Paraná (Reis et al. 2009) and approximately $31 \%$ of medium-sized and large mammals for the Atlantic Rainforest (Paglia et al. 2012, Reis et al. 2014). Although there is a stabilization of the species accumulation curve in our study (Fig. 34), other species may also occur in the park. In fact, sampling in 2016-2017 also included M. tridactyla, T. tetradactyla, M. nana, S. scrofa, C. brachyurus, G.brasiliensis, and $C$. spinosus to the final list. According to Srbek-Araujo and Chiarello (2007), periods longer than 250 days are sufficient for a faunal survey.

The species richness recorded in the PNCG is similar to that observed in other studies carried out in conservation units nearby. Borges (1989) reported 40 species of medium- sized to large mammals in Parque Estadual de Vila Velha, which is located $20 \mathrm{~km}$ from PNCG. In Reserva Biológica das Araucarias some $56 \mathrm{~km}$ from PNCG, the richness amounted to 28 species (D'Bastiani et al. 2018). In the Floresta Naciona de Irati, some $70 \mathrm{~km}$ from PNCG, 24 species of medium-sized to large mammals were recorded (Pereira and Bazilio 2014). Species such as M. nana, C. brachyurus, and M. tridactyla were not recorded at the Reserva Biológica das Araucarias and Floresta Naciona de Irati. Although these species have been reported by Borges (1989) for Parque Estadual de Vila Velha, he also included in his records sampling areas that are now part of PNGC.

The order Carnivora, with 12 species, is the order most recorded in ourstudy. According to Chiarello (2000), the group occurs with frequency in fragmented forest remnants. Species of Carnivora have great mobility and capacity in exploring man-disturbed environments close to native vegetation (Lyra-Jorge et al. 2010). Chrysocyon brachyurus was recorded by footprints and from accounts by farm workers near the park, is the largest South American canid, with adults weighing between 20 and $30 \mathrm{~kg}$ (Rodden et al. 2004). Although C. brachyurus is found mainly in the Campos Gerais region, it is there has been a reduction in its population numbers over the last decades. In fact, it has become scarce (Cherem and Perez 1996, Bazilio et al. 2011).

Five of the 7 species of felines in Paraná (Reis et al. 2009) occurred in the study area, specifically L. guttulus, L. pardalis, L. wiedii, P. yagouaroundi, and P. concolor. Our results corroborate those by Bastiani et al. (2015), who recorded practically the same species in the Floresta Nacional de Piraí (a 150 ha fragment some $83 \mathrm{~km}$ distance from PNCG). The low detection of several species of felines, such as L. guttulus and L. wiedii, may be due to competition for resources with large felines (Oliveira et al. 2010).

The presence of medium-sized and large mammals carnivore and herbivore species in the area studied indicates that the characteristics of the forest fragment enhance ecological processes for its maintenance. Herbivore animals disperse and control plant populations, whilst carnivores maintain herbivore populations (Santos et al. 2004, Pardini et al. 2004).

Of the threatened species in the PNCG, the presence of $M$. americana, M. nana, P. tajacu and C. paca is especially important because of their high conservation status in the state of Parana, which is linked to illegal hunting and trade in pelts (Cullen et al. 2000). PNCG is offers protection for these and other species.

According to Mazzolli (2006), P. tajacu is indicative of environmental quality because it has a low tolerance for disturbed habitats, and as a corollary, its absence is suggestive of highly disturbed habitat. Desbiez et al. (2012) demonstrated that the overlap in food resources and habitat use in Brazil between feral pigs and Tayassu pecari (Link, 1795) were lower than expected. In the Brazilian Pantanal, Galetti et al. (2015) found a great overlap in diets of T. pecari and feral pigs, but less overlap between $P$. tajacu and feral pigs. Nevertheless, feral pigs may impact the natural community in several other ways, such as eating eggs, destroying by rooting, and serving as vectors for disease (Desbiez et al. 2012, Galetti et al. 2015). 
The wild boar is in the list of 100 invading and heavily impacting species worldwide (Lowe et al. 2000). Loss of biodiversity and the extinction of native species caused by the introduction of wild pigs have already been documented (Wolf and Conover 2003). Competitive interaction with the wild boar mainly excludes peccaries (Gabor and Hellgren 2000, Galetti et al. 2015). At least 4 java pigs have been reported in the Alagadas Reservoir in northwestern PNCG. Piglets with spots characteristic of the java pig are common among other piglets with spots or common features of domestic pigs.

The domestic dog ( $C$. lupus familiaris) has been recorded on trails and roads, as well as within forests in PNCG. The presence of domestic animals may have serious ecological consequences for native fauna in conservation units (Rangel and Neiva 2013, Doherty et al. 2017). The predation of wild fauna by almost savage domestic dogs is compounded by direct competition for resources with native carnivores (Galetti and Sazima 2006). Exotic species are nowadays acknowledged to be the secondmost important threat to biodiversity, but also cause economic losses and pose serious risks to human health (Dorcas et al. 2012).

In the wake of processes that alter habitat, knowledge of biodiversity in conservation units is a basic requirement for management plans, proposals for conservation, and studies on ecological patterns and species distribution, (Silveira et al. 2010, Oliveira et al. 2017). Our study demonstrates the importance of PNCG as a haven for Paraná's medium-sized and large mammals. However, the occurrence of exotic and domestic species and the presence of hunters in the conservation unit underscore the need for more surveillance and monitoring, the repression of hunting, the control of exotic species, and the development of environmental education within the local community .

\section{Acknowledgements}

We thank the ICMBio team of the Parque Nacional dos Campos Gerais for its support in our research. Thanks are due to Juliane Coimbra Bczuska, Denise Bener, and Elvira D'Bastiani for their assistance in data collection. Thanks are also due to the Coordination for the Upgrading of Higher Education Personnel (Capes), the Araucária Foundation, and the Fundation Boticário for the Protection of Nature (in our second sampling year) for funding.

\section{References}

Almeida CG, Moro RS (2007) Análise da cobertura florestal no Parque Nacional dos Campos Gerais, Paraná, como subsídio ao seu plano de manejo. Terr@Plural 1 (1): 115-122.

Bastiani E, Bazilio S, Barros KF, Nabrzecki G (2015) Felinos da Floresta Nacional de Piraí do Sul, Paraná-Brasil. Acta zoológica mexicana 31 (1): 23-26.

Bazilio S, Schemczssen Z, Marques AC (2011) Registro visual do lobo-guará, Chrysocyon brachyurus (Illiger, 1815) (Mammalia: Carnivora: Canidae) na Floresta Nacional de Três Barras, SC. Biotemas 22
(4): 133-137. https://doi.org/10.5007/2175-7925.2009v22n4p133 Becker M, Dalponte JC (2013) Rastros de mamíferos silvestres brasileiros - Um guia de campo. Technical Books, Rio de Janeiro, 172 pp. Borges CRS (1989) Composição mastofaunística do Parque Estadual de Vila Velha, Ponta Grossa, Paraná, Brasil. Master thesis, Federal University of Curitiba, Curitiba, 358 p.

BRASIL (2010) Publicado no Diário Oficial $n^{\circ} 8233$, de 1 de junho de 2010. Reconhece e atualiza Lista de Espécies de Mamíferos pertencentes à Fauna Silvestre Ameaçadas de Extinção no Estado do Paraná e dá outras providências, atendendo o Decreto $N^{\circ} 3.148$, de 2004.

Cherem JJ, Perez DM (1996). Mamíferos terrestres de floresta de araucária no município de Três Barras, Santa Catarina, Brasil. Biotemas 9 (2): 29-46.

Chiarello AG (2000) Density and population size of mammals in remnants of Brazilian Atlantic Forest. Conservation Biology 14 (6): 1649-1657. https://doi.org/10.1111/j.1523-1739.2000.99071.x

Colwell RK (2009) EstimateS 8.2 User's Guide: Statistical estimation of species richness and shared species from samples. Version 8.2. http://priede.bf.lu.lv/ftp/pub/TIS/datu_analiize/EstimateS/EstimateSUsersGuide.htm Accessed on: 2017-12-12.

Cullen JRL, Bodmer RE, Pádua CV (2000) Effects of hunting in habitat fragments of the Atlantic Forest, Brazil. Biological Conservation 95 (1): 49-56. https://doi.org/10.1016/S0006-3207(00)00011-2

Derhé MA, Murphy HT, Preece ND, Lawes MJ, Menéndez R (2017) Recovery of mammal diversity in tropical forests. Restoration Ecology 26 (4): 778-786. https://doi.org/10.1111/rec.12582

DesbiezALJ, Santos SA, Keuroghlian A, Bodmer RE (2012). Niche partitioning among white-lipped peccaries (Tayassu pecari), collared peccaries (Pecari tajacu), and feral pigs (Sus scrofa). Journal of Mammalogy 90 (1): 119-128. https://doi.org/10.1644/08-MAMMA-038.1

Doherty TS, Dickman CR, Glen AS, Newsome TM, Nimmo DG, Ritchie EG, Vanak AT, Wirsing AJ (2017) The global impacts of domestic dogs on threatened vertebrates. Biological Conservation 210: 56-59. https://doi.org/10.1016/j.biocon.2017.04.007

Dorcas ME, Willson JD, Reed RN, Snow RW, Rochford MR, Miller MA, Meshaka WE, Andreadis PT, Mazzotti FJ, Romagosa CM, Hart KM (2012) Severe mammal declines coincide with proliferation of invasive Burmese pythons in everglades National Park. Proceedings of the National Academy of Sciences 109 (7): 2418-2422. https://doi.org/10.1073/pnas.1115226109

Gabor TM, Hellgren EC (2000) Variation in peccary populations: landscape composition or competition by an invader? Ecology 81 (9): 2509-2524. https://doi.org/10.1890/0012-9658(2000)081[2509:VI PPLC]2.0.CO;2

Galetti M, Sazima I (2006) Impacto de cães ferais em um fragmento urbano de Floresta Atlântica no sudeste do Brasil. Natureza \& Conservação 4 (1): 58-63.

Galetti M, Camargo H, Siqueira T, Keuroghlian A, Donatti CI, Jorge MLSP, Pedrosa F, Kanda CZ, Ribeiro MC (2015) Diet Overlap and Foraging Activity between Feral Pigs and Native Peccaries in the Pantanal. Plos ONE 10: e0141459. https://doi.org/10.1371/journal. pone. 0141459

IUCN (2018) International Union for Conservation of Nature and Natural Resources. Red List of Threatened Species. Version 2018. http://www.iucnredlist.org/. Accessed on: 2018-12-1.

Kasper CB, Mazim FD, Soares JBG, Oliveira TG, Fabián ME (2007) Composição e abundância relativa dos mamíferos de médio e grande porte no Parque Estadual do Turvo, Rio Grande do Sul, Brasil. Revista Brasileira de Zoologia 24 (4): 1087-1100. https:// doi.org/10.1590/S0101-81752007000400028

Lowe S, Browne M, Boudjelas S, Poorter M (2000) 100 of the world's worst invasive alien species a selection from the global invasive species database. Nova Zelandia: The Invasive Species Specialist Group (ISSG) a specialist group of the Species SurvivalCommission (SSC) of the World Conservation Union (IUCN), Gland, 12 pp. 
Lyra-Jorge MC, Ribeiro MC, Ciocheti G, Tambosi LR, Pivello VR (2010) Influence of multi-scale landscape structure on the occurrence of carnivorous mammals in a human-modified savanna. Brazil. European Journal of Wildlife Research 56 (3): 359-368. https:// doi.org/10.1007/s10344-009-0324-X

Maack R (2017) Geografia Física do Estado do Paraná. 4.ed. Editora UEPG, Ponta Grossa, 526 pp.

Magioli M, Ribeiro MC, Ferraz KMPMB, Rodrigues MG (2015) Thresholds in the relationship between functional diversity and patch size for mammals in the Brazilian Atlantic Forest. Animal Conservation 18 (6): 499-511 https://doi.org/10.1111/acv.12201

Mazzolli M (2005) Efeito de gradientes de floresta nativa em sistemas agropecuários sobre a diversidade de mamíferos vulneráveis. Relatório Técnico, WWF, Brasília 26 pp.

Mazzolli M (2006) Persistência e riqueza de mamíferos focais em sistemas agropecuários no planalto meridional brasileiro. $\mathrm{PhD}$ thesis, Federal University of Rio Grande do Sul, Porto Alegre, 105 pp.

Myers N, Mittermeier RA, Mittermeier CG, Fonseca GAB, Kent J (2000) Biodiversity hotspots for conservation priorities. Nature 403: 853-858. https://doi.org/10.1038/35002501

Miller B, Dugelby B, Foreman D, Del Río CM, Noss R, Phillips M, Reading R, Soulé ME, Terborgh J, Willcox L (2001) The Importance of Large Carnivores to Healthy Ecosystems. Endangered Species UPDATE 18 (5): 1-10.

MMA (2014) Portaria do Ministério do Meio Ambiente no 444, de 17 de dezembro de 2014. Lista Nacional Oficial de Espécies da Fauna Ameaçadas de Extinção. Diário Oficial da União, Brasília, n. 245, 18 dez. 2014. Seção I, p. 121-126.

Moro RS (2001) A vegetação dos Campos Gerais da escarpa devoniana. In: Ditzel CDHM, Sahr CLL (Eds) Espaço e Cultura: Ponta Grossa e os Campos Gerais. Editora UEPG, Ponta Grossa, 481-503.

Oliveira TG, Cassaro K (2006) Guia de campo dos felinos do Brasil. Instituto Pró - Carnívoros: Fundação Parque Zoológico de São Paulo: Sociedade de Zoológicos do Brasil, Pró -Vida Brasil, São Paulo, $80 \mathrm{pp}$

Oliveira EA (2012) O Parque Nacional dos Campos Gerais: processo de criação, caracterização ambiental e proposta de priorização de áreas para regularização fundiária. $\mathrm{PhD}$ thesis, Federal University of Paraná, Curitiba, 293 pp

Oliveira U, Soares-Filho BS, Paglia AP, Brescovit AD, Carvalho CJB, Silva DP, Rezende DT, Leite FSF, Batista JAN, Barbosa JPPP, Stehmann JR, Ascher JS, Vasconcelos MF, De Marco P, Löwenberg-Neto P, Ferro VG, Santos AJ (2017) Biodiversity conservation gaps in the Brazilian protected areas. Scientific Reports 7: 9141. https://doi.org/10.1038/s41598-017-08707-2

Oliveira TG, Tortato MA, Silveira L, Kasper CB, Mazim FD, Lucherini M, Jácomo AT, Soares JBG, Marques RV, Sunquist M (2010) Ocelot ecology and its effect on the small-felid guild in the lowland neotropics. In: Macdoweld DW, Loveridge AJ (Eds) Biology and conservation of wild cats. Oxford University Press, Oxford, 559-580.

Paglia AP, Fonseca GAB, Rylands AB, Herrmann G, Aguiar LMS, Chiarello AG, Leite YLR, LeiteYLR, Costa LP, Siciliano S, Kierulff MCM, Mendes SL, Tavares V, Mittermeier RA, Patton JL (2012) Annotated checklist of Brazilian mammals. Occasional Papers in Conservation Biology 6: 1-82.

Pardini R, Ditt EH, Cullen Junior L, Bassi C, Rudran R (2004) Levantamento rápido de mamíferos terrestres de médio e grande porte. In: Cullen Junior L, Rudran R, Valladares-Pádua C (Eds) Métodos de estudos em Biologia da Conservação e Manejo da Vida Silvestre. Ed. da UFPR, Fundação O Boticário de Proteção à Natureza, Curitiba, 181-201.

Patton JL, Pardiñas, UF, D’Elía G (2015) Mammals of South America. Volume 2. Rodents. University of Chicago Press, Chicago, 1384 pp.

Rangel CH, Neiva CHMB (2013) Predação de Vertebrados por Cães Canis lupus familiaris (Mammalia: Carnivora) no Jardim Botânico do Rio de Janeiro, RJ, Brasil. Biodiversidade Brasileira 3 (2): 261-269.

Reis NR, Peracchi AL, Fragonezi MN, Rossaneis BK (2009) Guia ilustrado mamíferos do Paraná - Brasil. Editora USEB, Pelotas, 264 pp.

Reis NR, Peracchi AL, Pedro WA, Lima IP (2011) Mamíferos do Brasil, 2 ed. Nélio R. dos Reis, Londrina, 439 pp.

Reis NR, Fragonezi MN, Peracchi AL, Shibatta OA, Sartore ER, Rossaneis BK, Santos VR, Ferracioli P (2014) Mamíferos terrestres de médio e grande porte da Mata Atlântica: guia de campo. Technical Books, Rio de Janeiro, 146 pp.

Rodden M, Rodrigues FHG, Bestelmeyer SV (2004) Maned wolf (Chrysocyon brachyurus). In: Sillero-Zubiri C, Hoffmann M, Macdonald DW (Eds) Canids: foxes, wolves, jackals and dogs: Status Survey and Conservation Action Plan. IUCN/SSC Canid Specialist Group, IUCN, Gland, Switzerland and Cambridge, 38-44.

Santos MFM, Pellanda M, Tomazzoni AC, Hasenack H, Hartz SM (2004) Mamíferos carnívoros e sua relação com a diversidade de hábitats no Parque Nacional dos Aparados da Serra, sul do Brasil. Iberingia Série. Zoológica 94 (3): 235-245. https://doi.org/10.1590/ S0073-47212004000300003

Silveira LF, Beisiegel BM, Curcio FF, Valdujo PH, Dixo M, Verdade VK, Mattox GMT, PTM Cunningham (2010) Para que servem os inventários de fauna? Estudos Avançados 24 (68): 173-207. https:// doi.org/10.1590/S0103-40142010000100015

SNUC (2000) Sistema Nacional de Unidades de Conservação; Lei 9.985 de 18 de julho de 2000; Ministério do Meio Ambiente. http:// www.mma.gov.br/port/conama/legiabre.cfm?codlegi=322. Accessed on: 2018-10-1.

SOS Mata Atlantica \& INPA - Instituto Nacional de Pesquisas Espaciais. 2018. Atlas dos remanescentes florestais da Mata Atlântica - Período 2016-2017. Relatório técnico, São Paulo, 66 pp.

Srbek-Araujo AC, Chiarello AG. 2007. Armadilhas fotográficas na amostragem de mamíferos: considerações metodológicas e comparação de equipamentos. Revista Brasileira de Zoologia 24 (3): 647-656. https://doi.org/10.1590/S0101-81752007000300016.

Srbek-Araujo AC, Chiarello AG (2013) Influence of camera-trap sampling design on mammal species capture rates and community structures in southeastern Brazil. Biota Neotropica 13 (2): 51-62. https://doi.org/10.1590/S1676-06032013000200005

Terborgh J, Estes J, Paquet P, Ralls K, Boyd-Heger D, Miller B, Noss $\mathrm{R}$ (1999) The role of top carnivores in regulating terrestrial ecosystems. In: Soule ME, Terborgh J. (Eds) Continental Conservation: Scientific Foundations of Regional Reserve Networks. Island Press, Washington, DC, 39-64.

Trigo TC, Schneider A, Oliveira TG, Lehugeur LM, Silveira L, Freitas, TRO, Eizirik E (2013) Molecular data reveal complex hybridization and cryptic species of Neotropical wild cat. Current Biology 23 (24): 2528-2533. https://doi.org/10.1016/j.cub.2013.10.046

Wolf T, Conover MR (2003) Feral pigs and the environment: an annotated bibliography. Berryman Institute Publication 21. Utah State University, Logan, and Mississippi State University, Starkville, 92 pp. 